\title{
Micro-Damage Propagation in Marble under Triaxial State of Stress*
}

\author{
by Gyo-Cheol JEONG ${ }^{1}$ and Yasuaki ICHIKAWA ${ }^{2}$
}

\begin{abstract}
Microcracking and micro-damage model in fine-grained homogeneous marble was simulated with a basis on the stress intensity factors, and investigated by experimental system designed newly. The model allows for the growth of microcracks from starting microcracks, that is, triple-point junctions on a regular array of pre-existing grain boundary microcracks. Axial grain boundary microcracks of the mode I type begin to grow at the onset of sliding in inclined microcracks, which is the dominant mechanism of microcrack damage. This growth occurs rapidly along the $K_{I}(1)$ concentration paths created by the grain boundaries. Thus we can observe both sliding for the inclined grain boundaries and opening for the microcracks which are parallel to the stress $\sigma_{1}$.

A microcrack damaged zone is developed by the dislocation of calcite in marble resulted from the sliding. Thus, the damaged zone depends on confining pressure, and resultingly, the highly damaged area decreases with increasing confining pressure.
\end{abstract}

KEY WORDS : Micro-damage, Triple-point Junction, Pre-existing Microcrack, Grain Boundary Microcrack, Damaged Zone

\section{Introduction}

Pre-existing microcracks are commonly, found in the quartz phase of igneous and metamorphic rocks ${ }^{1)}$ and frequently planes of fluid inclusions are observed ${ }^{2)}$. Most microcracks in igneous and metamorphic rocks are caused by tensile stress (mode I type of fracture, open crack), which are classified into grain boundary and intracrystalline microcracks. Marble which is treated here is one of the typical metamorphic rocks.

The mechanical properties of the crystalline rock such as marble may significantly be affected by the microcracks. The inelastic deformation of rocks may consist of reopening, sliding and/or nucleation of microcracks. Therefore, a sophisticated mechanical model is required, which can take into account for inhomogeneous distribution of minerals, and microcrack behavior. Microcracks found in marble are formerly of open type, which have been healed and sealed by secondary or remobilized minerals during metamorphism. The microcracks are called as healed microcracks. Microscopic observations of rock specimens that have been stressed in compression to loads greater than about one third of their uniaxial strength show that formation and growth of microcracks are nearly parallel or subparallel to the direction of the principal stress.

White et al. ${ }^{3)}$ state that grain boundaries in rocks commonly form relatively wide zone $(10-100 \mathrm{~nm})$ of disordered crystal structure along which fluid-filled voids and/or amorphous hydrated layers are found. As such, they are analogous to arrays of pre-existing microcracks filled with potentially corrosive agents and they suggest that stress corrosion can be expected to concentrate along grain boundaries.

In the present study, a mathematical model based on some experimental observations is presented to understand microcrack growth and damage variation at low confining

* Received July 19, 1993 : accepted for publication October 8, 1993

1, 2. Faculty of Engineering, Nagoya University, Chikusa-ku, Nagoya 464 01, Japan

1. Graduate Student, 2. Associate Profeesor, D. Eng. pressure. It is concluded that micro-damages in crystalline rocks play an important rule in formation and growth of macrocracks.

\section{Experiments}

The microcrack growth and subsequent damage examined in this study were carried out in a suite of compression test on nominally dry fine-grained marble at room temperature. All specimens were made from a block of the marble from Jinan, Korea by arranging the cut-planes in the same direction.

$2 \cdot 1$ Experimental procedure

The experimental system, consisting of three subsystems, (a) loading system, (b) data-recording system and (c) observation system, is illustrated in Fig. 1. The loading system used in this experiment is designed (Fig. 2). The dimension of a specimens used in the compression test is shown in Fig. 3. The loading area of the specimen is $20 \mathrm{~mm} \times 5 \mathrm{~mm}$ and all surface were ground polished to observe easily the behavior by the stereoscopic microscope.

First of all, the marble specimen with mounted strain gauge is placed on a concave steel plate with a dimensions of 36 $\mathrm{mm} \times 20 \mathrm{~mm} \times 4 \mathrm{~mm}$ in a pressure vessel. Concave shape of the steel plate was prepared to offer space fixing strain gauge beneath of the specimen. Next, the specimen is deformed by axial stress applied through the loading pump on the left hand side of Fig. 1. The stress is applied by a piston actuated through an external, manually controlled pressure system. Axial stress and strain applied to the specimens are recorded by using a personal computer.

In order to observe directly the initiation and growth pattern of microcracks from the pre-existing grain boundary microcracks between grains and the debonding of the twin lamellae in grains while an axial stress is applied to the specimen, a stereoscopic microscope (Nikon, SMZ-U) with magnifying power of 110 time is used, and more detailed observation by a scanning electron microscope (SEM) is carried out to determine the size of the pre-existing microcrack. Video monitoring through the CCD camera for continuous recording and a $\mathrm{F}$ mount camera for intermittent recording of the specimen are performed. 


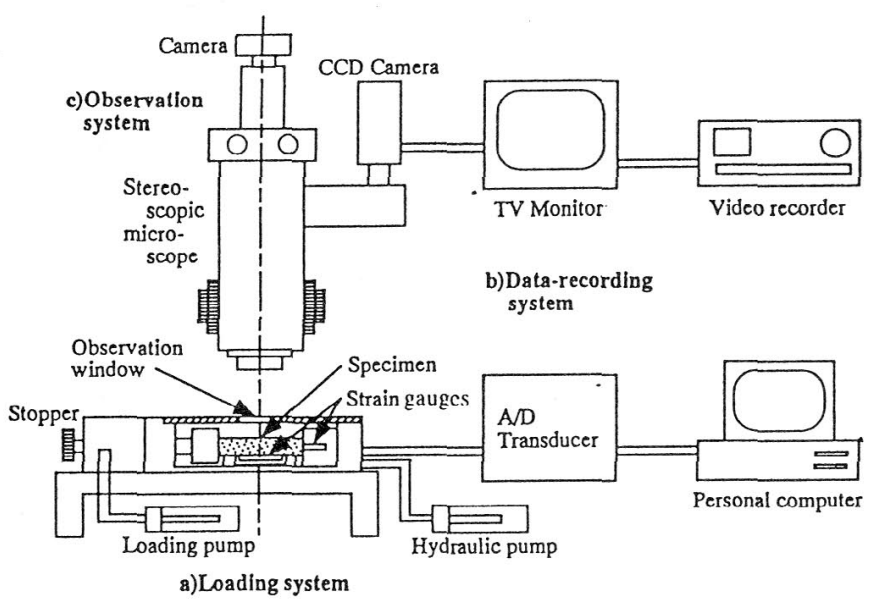

Fig. 1 Experimental systems;(a) loading system, (b) datarecording system and (c) observation system.

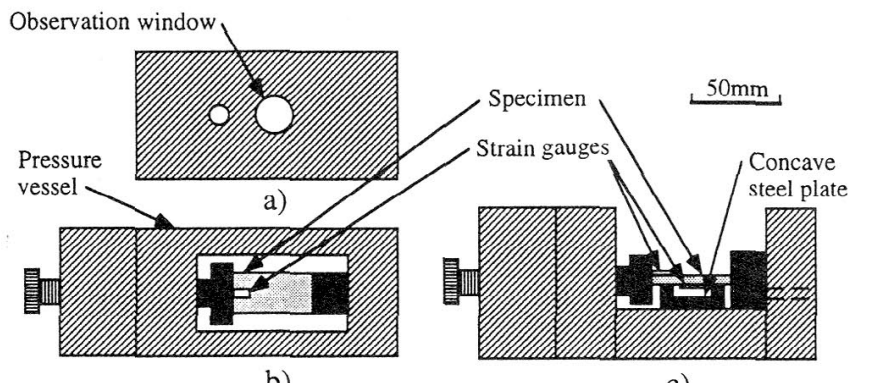

b)

c)

Fig. 2 Specimen and each part assembly of loading system used for compression tests; (a) lid for observing, (b) confining pressure vessel and (c) front of the confining pressure vessel.

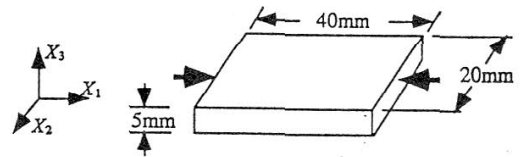

Fig. 3 Dimensions of the specimen and coordinate axes; axis of compression parallel to $\mathrm{X}_{1}$.

\section{2 - 2 Microcrack initiation and growth}

Active deformation mechanism in the marble used in this study include microcracking, twinning and dislocation glide. The microcrack initiation mechanisms observed in Tennessee marble were idealized by Olsson et al. ${ }^{4)}$ (Fig. 4 ). In the instance of type (a), a packet of twin lamellae which are intersected a grain boundary causes the tensile stress concentration which nucleates the microcrack. The type (b) microcrack is not frequently observed in marble. Hence, this mechanism probably does not contribute to the microcracking during the actual deformation of the marble. The type (c) mechanism does not require the presence of a grain boundary. Thus this mechanism can nucleate microcracks in single crystals as well as polycrystals. These particular types of microcrack were not often observed in the present study. The type (d) mechanism is comprised of a plastically yielding grain boundary surrounded by non-yielding grains. Most of damage due to microcracking of the marble used in the present study consists of type (d) of Fig. 4 , especially the type (1) in this figure.

Due to the direction of the microcracks, we have

(a) axial microcracks, and

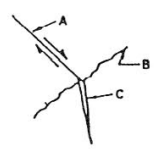

(a)<smiles>CC#CC1CCCC1CC</smiles>

(c)

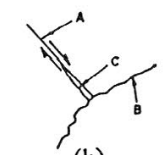

(b)

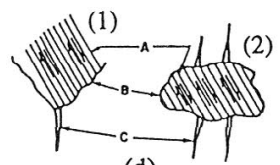

(d)
Fig. 4 Schematic diagram of the principal microcrack nucl-eation mechanisms observed in marble (Olsson et al.). ${ }^{4)}$ Maximum compression is vertical. The single-sided arrows indicate displacement on twin ; A : glide twin, B : grain boundary, C : stressed grain boundary microcrack.

(b) inclined microcracks.

The axial microcracks (opening mode ; mode I ) are found by stress concentration, which is caused by incompatibility of mechanical properties. The inclined microcracks (shearing mode; mode II ) are developed because of the inclined grain boundaries or the cleavage planes (intracrystalline gliding planes) of minerals or the coalescence of a series of isolated short microcracks. SEM observations by Olsson et al. ${ }^{4)}$ indicate that dislocation glide occurs at inclined grain boundaries. Grain boundary glide has been suggested as a mechanism for creating microcracks at grain boundary triple junctions, and at asperities on the boundary itself. Most stress-induced mode I microcracks are parallel or nearly parallel to the maximum stress direction. A large number of these microcracks are associated with point contacts of greatly different elastic modulus. ${ }^{5)-77}$ A stress concentration is also found at these point contacts, and intercrystalline microcracks pass through the point contacts.

In this study, it is defined that a stress-induced microcrack is introduced if a healed pre-exiting microcrack becomes fully open. The microcrack growth is of the opening mode at triplepoint junctions of grains and of the shearing mode at inclined grain boundaries. Monomineralic materials such as marble are characterised by a fine, and uniform grain structure and by the presence of very fine pores at triple-point junctions. Therefore, the failure of marble happens because of propagation of wedge-microcrack at triple-point junctions of grains (Fig. 5). The rapid growth of microcracks of the shear mode

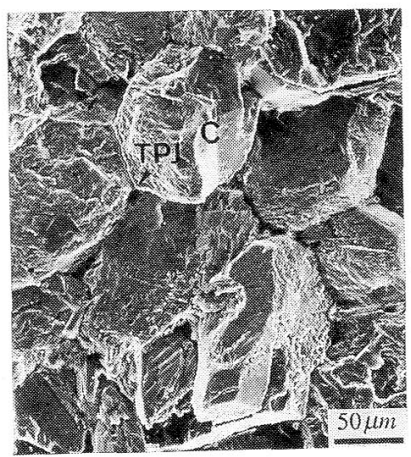

Fig. 5 Scanning electron microscopy (SEM) micrographs showing triple-point junction (TPJ) consisting of calcite (C) grain boundaries. 
is found on shear stress planes.

\section{Homogeneous Three-Grain Model}

As shown above, most stress-induced microcracks are initiated at triple-point junctions and propagated through the healed pre-existing microcracks. The stressinduced microcracks are nearly parallel to the maximum compressive stress. To clarify this micromechanics, we calculated the damage value due to external stress, and variation of Young's modulus due to damage value is computed by using the four-grain model proposed by $\mathrm{Fu}$ et $a{ }^{8}{ }^{8)}$ for analysis of thermal stress primarily.

\section{3 - 1 Damaging from pre-existing microcrack}

The initiation and propagation of micro-damages are determined by using the stress intensity factor $K_{I}$ (mode I , tensile microcrack growth) and fracture toughness $K_{I C .} K_{I}$ is dominated by the open of the triple-point junction caused by the sliding of the initial inclined microcrack, and influenced by the confining stress. When $K_{I}$ at the tip of the triple-point junction is equal to, or exceeds $K_{I C}$, stress-induced microcrack grows. The condition microcrack advance is simply

$$
K_{I} \geq K_{I C}
$$

However, we may note that there is another contribution $K_{I(3)}$ to $K_{I(1)}$ acting in a stress intensity tending to open the microcrack under the triaxial state of stress, which means that confining stress $\sigma_{3}$ produces an additional contribution to the stress intensity $K_{I(1)}$, tending to close the microcrack when $\sigma_{3}$ is compressive. Therefore, we now require the following advanced condition for microcrack growth under the triaxial stress state :

$$
K_{I(1)} \geq K_{I C}-K_{I(3)}
$$

The stress field is composed of a shear stress $\tau$ and a normal stress $\sigma_{n}$ across faces of the inclined microcrack. The microcrack slides, wedging open the mouth of each triplepoint junction. Let $P_{3}$ be a opening force caused by sliding in inclined microcrack, which is acting on the opening plane shown in Fig. 6 . Then the stresses $\tau$ and $\sigma_{n}$ are given by

and

$$
\sigma_{n}=\frac{\sigma_{1}+\sigma_{3}}{2}-\frac{\sigma_{1}-\sigma_{3}}{2} \cos 2 \theta \quad \ldots \ldots \ldots \ldots \ldots \ldots \ldots \ldots(3)
$$

$$
\tau=-\frac{\sigma_{1}+\sigma_{3}}{2} \sin 2 \theta
$$

and $P_{3}$ is simply the component at the sliding force:

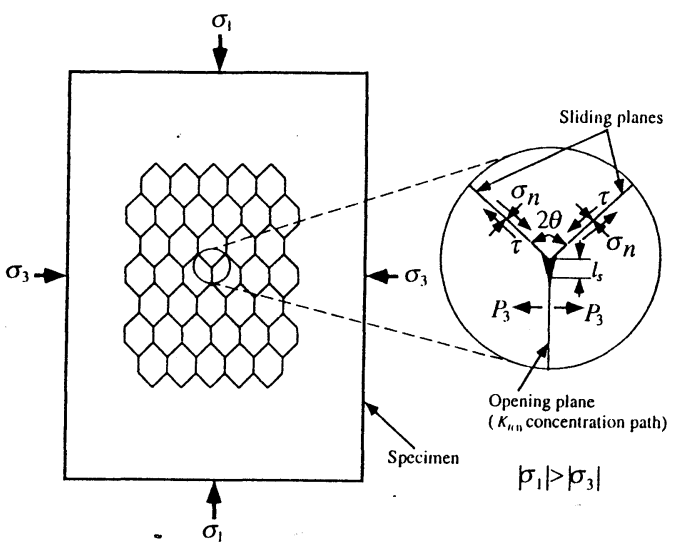

Fig. 6 Homogeneous three-grain model showing high stress intensity near tip of triple-point junction.
$P_{3}=\left(\tau+\mu \cdot \sigma_{n}\right) \cdot \beta \cdot 2 a \cdot \sin \theta$

where $\mu$ is the coefficient of friction acting across the microcrack faces, $\beta$ is the constant concerning to microcrack nucleation, and $L=2 a$ is the length of the pre-existing microcrack. Note that $\beta$ is determined by experiments as show later in Eqn (10).

Substituting Eqns (3) and (4) into (5) yields

$$
P_{3}=\beta \cdot a\left(\sigma_{3} A-\sigma_{1} B\right)
$$

where $A$ and $B$ are constants which depend on $\theta$ such that

$$
\left.\begin{array}{l}
A=\sin 2 \theta \cdot \sin \theta+\mu \sin \theta+\mu \cos 2 \theta \cdot \sin \theta \\
B=\sin 2 \theta \cdot \sin \theta-\mu \sin \theta+\mu \cos 2 \theta \cdot \sin \theta
\end{array}\right\}
$$

The wedging of a grain into a pre-existing microcrack in Fig. 6 causes a force that acts to open the microcrack. This force, whose component perpendicular to the microcrack is $P_{3}$, causes a stress intensity tending to open the axial preexisting microcrack. ${ }^{9)}$ However, when a length of crack $l$ is large, the stress intensity at the tip of a crack is well estimated, but it becomes infinite when $l$ is vanishingly small. To overcome this problem, Sammis et al. ${ }^{10)}$ have estimated the stress intensity by introducing an effective crack length $(l+\alpha \cdot$ 2 a) including microcracking of inclined pre-existing microcrack giving

$$
K_{I(1)}=2.6 P_{3} / \sqrt{\pi(l+\alpha \cdot 2 a)}
$$

where $l$ is the stressed microcrack length and $\alpha=\cos \theta$.

$K I(3)$ of Eqn (2) is due to the confining pressure trying to close the microcrack. The confining stress $\sigma_{3}$ acts not just on the inclined microcrack but on the axial microcrack of length $l$ as well. In so doing, it produces an additional contribution to the stress intensity, tending to close the microcrack when $\sigma_{3}$ is compressive ${ }^{11)}$

$$
K_{I(1)}=-\sigma_{3} \sqrt{\pi l}
$$

Substituting Eqns (8) and (9) into (2), microcrack initiation and propagation condition becomes

$$
\sigma_{1} \geq \frac{2 \sqrt{\pi(D+\alpha)}}{2.6 \beta B}\left(\frac{K I C}{\sqrt{2 a}}+\sigma_{3} \sqrt{\pi D}\right)+\frac{A}{B} \sigma_{3} \cdots \cdots \cdots(10)
$$

where $D=l / L$, normalized microcrack length, is the damage parameter, $\mu$ is a friction coefficient of calcite consisting of marble which is of the value about $0.6^{12)}$ and $\beta$ is estimated as 4 from our experimental results that a stress-induced microcrack is initiated from the triple-point junction at a stress level $28 \mathrm{MPa}$. A wedge angle of $2 \theta=90^{\circ}$ from the typical calcite structure was used, and critical stress intensity factor KIC of the marble used in this study can be obtained from the results of the three-point bending test carried out by Kim

${ }^{13)}, K_{I C}=0.8 \mathrm{MPa} \mathrm{m}{ }^{1 / 2}$ was used. As a result, Eqn (10) with these values of $A, B, \beta$ and $K_{I C}$ is plotted in Fig. 7. Note that the point of $D=0$ is determined by the data of microcrack initiation. Overall level of the axial stress-normalized microcrack length curve increases with confining stress $\sigma_{3}$. Experiment under uniaxial compression was carried out at various stress level for measuring stress-induced microcrack lengths. The lengths were measured by using micrometer and microphotographs through the stereoscopic microscope. The experimental results are shown in Fig. 7 . It is seen that the solution agrees well with experimental results. Whereas, we 


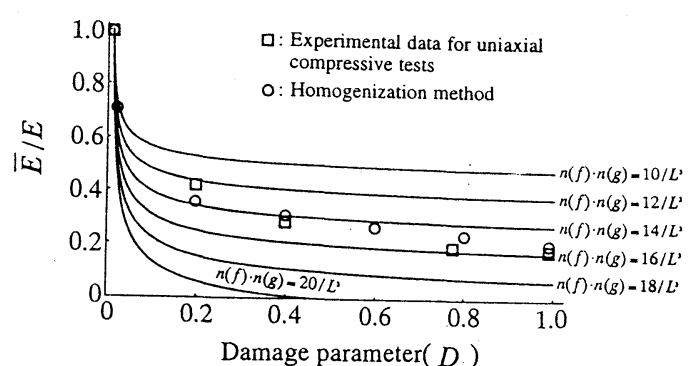

Fig. 7 Axial stress-damage parameter relations at various confining pressures.

could not observe microcrack propagation under triaxial state of stress because of the poor visible condition. The triaxial test equipment is needed to be improved further.

\section{2 Damaging and elastic modulus}

In order to determine how the effective Young's modulus affects the damage parameter $D$, a parameter for describing the microcrack density should be introduced. The state of microcracking can be characterized by means of a scalar internal variable $N \cdot a^{3}$. Here $N \cdot a^{3}$ provides a measure of microcrack density, where $N$ is the number of microcracks per unit volume, $a$ is the length of the microcrack. For instance, using a self-consistent method, Budiansky et al. ${ }^{14)}$ computed the effective moduli of a solid containing randomly distributed microcracks to be

$$
\frac{\bar{E}}{E}=1-\frac{16}{45} \frac{\left(1-\bar{v}^{2}\right)(10-3 \bar{v})}{(2-\bar{v})} N \cdot a^{3}
$$

when $\bar{E}$ and $\bar{v}$ denote the effective Young's modulus and poisson's ratio, respectively, and $E$ is the Young's modulus of the intact solid. Furthermore in the range of $\bar{E} \geqq 0.2 E$, the following approximation pertains

$$
\frac{\bar{E}}{E}=1-\frac{16}{9} N \cdot a^{3}
$$

and the number of microcracks per unit volume that $\mathrm{Fu}$ et al. ${ }^{8)}$ estimated by using the fraction of microcracked facets in the two-dimensional array is equivalent to the following Eqn :

$$
N=\frac{n(f) \cdot n(g)}{2 \pi} \cos ^{-1} \sqrt{\frac{l_{s}}{2 a D}}
$$

where $n(f)$ is the number of facets per grain, $n(g)$ is the number of grains in a unit volume, and $l s$ is the length of the triplepoint junction (see Fig. 6 ). The $l s$ is estimated as about 1.5 $\mu \mathrm{m}$ from our SEM observations.

Therefore, the relation of the effective Young's modulus of a polycrystal containing facet-sized grain boundary microcrack to damage parameter becomes

$$
\frac{\bar{E}}{E}=1-\left(\frac{n(f) \cdot n(g) L^{3}}{9 \pi}\right) \cos ^{-1} \sqrt{\frac{l_{s}}{2 a D}} \cdots \cdots \cdots \cdots \cdots(14)
$$

Fig. 8 shows the reduction in the Young's modulus as a function of the damage parameter $(D)$ in various facet densities. The simulated results were compared with experimental results for uniaxial compressive tests and values obtained by using Homogenization method ${ }^{15)}$. Resultingly, the facet density of the marble is more closely approximately by $n(f) \cdot n(g)$ $=14 / L^{3}$. That is, as shown in the figure, the simulated results with the facet density agrees well with the experimental results and the homogenization analysis. Damage parameter

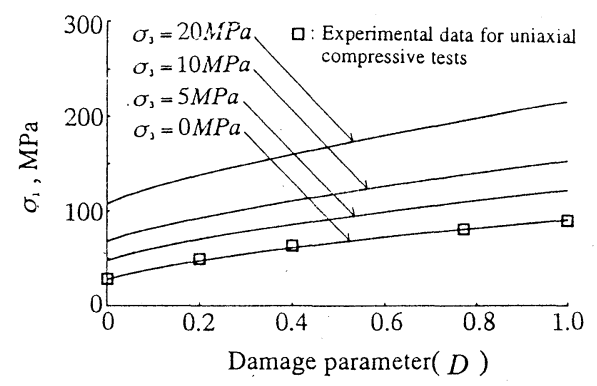

Fig. 8 Normalized Young's modulus-damage parameter relations at various facet densities.

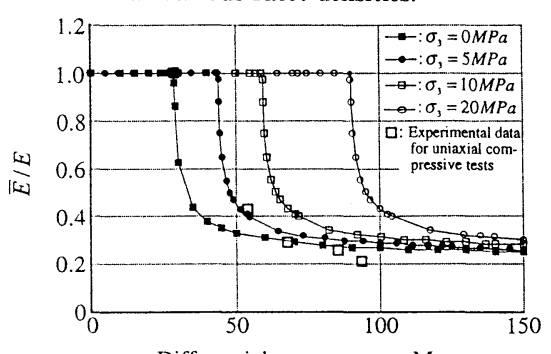

Differential stress $\sigma_{1}-\sigma_{3}$, Mpa

Fig. 9 Normalized Young's modulus-differential stress relations at various confining pressures.

(D) depends on differential stress $\sigma_{1}-\sigma_{3}$. Note that the equality of (10) is satisfied when microcracks are propagating. Then, substituting Eqn (10) into (14), we get Fig. 9 . The experimental results are also shown in this figure.

\section{Effects of Confining Pressure on Micro-damage Localization}

The damaged zone of a rock specimen under uniaxial and triaxial stress state is governed by the growth and coalescence of microcracks. This process depends on the disorder in the grains consisting of the rock.

Post-failure specimens exhibit significantly higher microcrack densities, and are classified in three zones such as highly damaged one, slightly damaged one and undamaged one (Fig.10). The intensity of the damaged zones is classified by observing microphotographs. The microscopic structure of the undamaged zone is characterized by the healed pre-existing grain boundary microcracks and very low density of twins (Fig. 10(a)). Under loading, optical observations indicate that deformation mechanisms include microcracking, twinning, and dislocation glide. The slightly damaged zone indicates a slight increase in the density of twins (Fig. 10 (b)), and suggests that in the semibrittle field in which the Mohr-Coulomb friction law is considered for the triple junction behavior, twinning is the dominant element for the initial yield. The density of twins increases with axial strain at constant confining stress $\sigma_{3}$. Twin geometries are quite complex, with two and sometimes three sets of twins active in a single grain. The highly damaged zone consists of opened grain boundary, intracrystalline and intercrystalline microcracks (Fig. 10 (c)). Grain boundaries that lie parallel to $\sigma_{1}$ may grow and link up stress-induced microcrack because the grain boundary may provide less resistance to microcrack propagation than the interior of a grain. Intercrystalline microcracks extending over three or five grains are common in the highly damaged zone from microphotographs, and the highly damaged zone is 

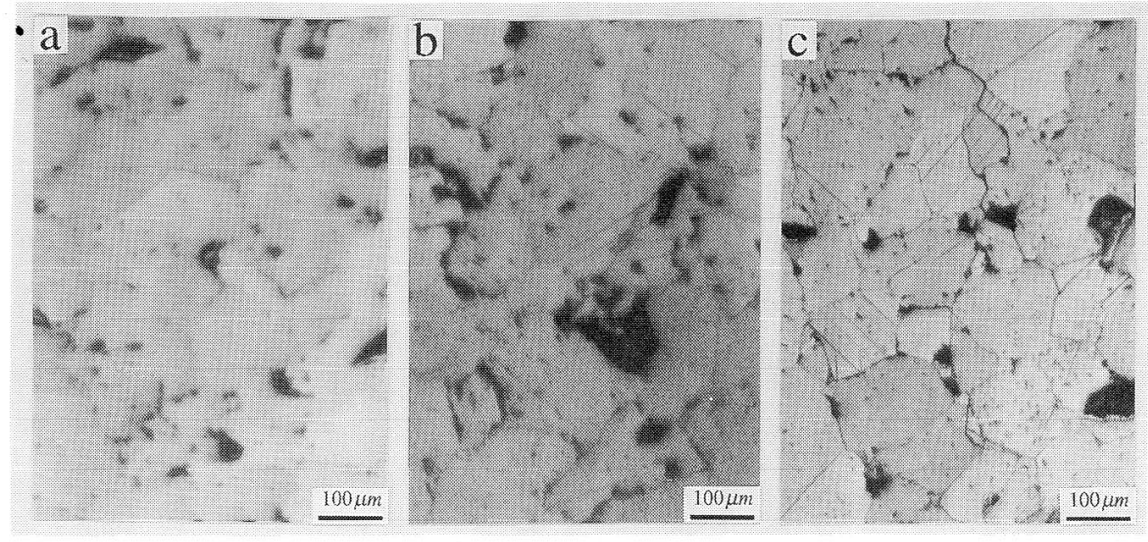

Fig. 10 Microphotographs showing (a) pre-existing grain boundary microcracks and very low density of twins (undamaged zone), (b) stress-induced grain boundary microcracks and slight increase in the density of twins (slightly damaged zone), and (c) highly damaged zone consisting of open grain boundary and intracrystalline microcracks, and especially intercrystalline microcrack extending over four grain boundaries is observed in (c).

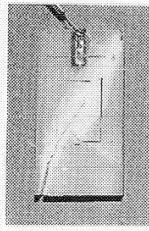

(a)

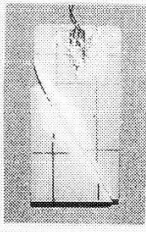

(b)

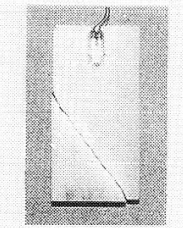

(c)

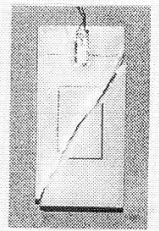

(d)

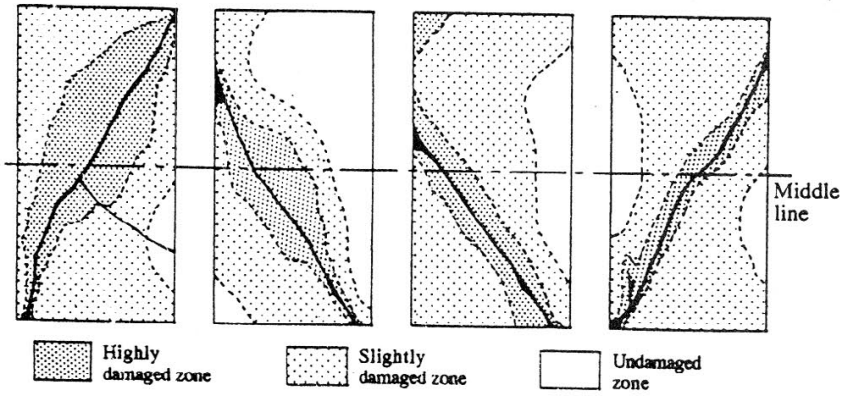

Fig. 11 Damaged and undamaged zones after failure at low confining pressures of (a) $0 \mathrm{Mpa}$, (b) $1 \mathrm{Mpa}$, (c) 2 Mpa, and (d) $4 \mathrm{Mpa}$. The intensity of the damaged zone is classified by microscopic photographs. Solid bold line is shear fracture line.

characterized by white color in contrast to the surrounding slighly damaged zone (Fig. 11), whereas a few grain boundary and intracrystalline microcracks are distributed in slightly damaged zone. In this damaged zone, no intercrystalline micro crack is observed.

To observe effects of confining pressure on micro-damage localization, the three damaged zones were sketched by microscopic observations and photomicrographs after shear fracture (Fig. 11). Resultingly, area of the damaged zone depends on confining pressure, especially the area of the highly damaged zone decreases with increasing confining pressure and the features of highly damaged zone is of lens-shaped in zero confining pressure, and of slender column-shaped in increased confining pressure. The highly damaged zone would play an important role for initiation and propagation of shear failure. Normalized highly damaged area A (that is, the rate of the highly damaged area to the whole area; the unit is $\mathrm{mm}^{2} / \mathrm{mm}^{2}$ ) and the width of the damaged part along the middle line of

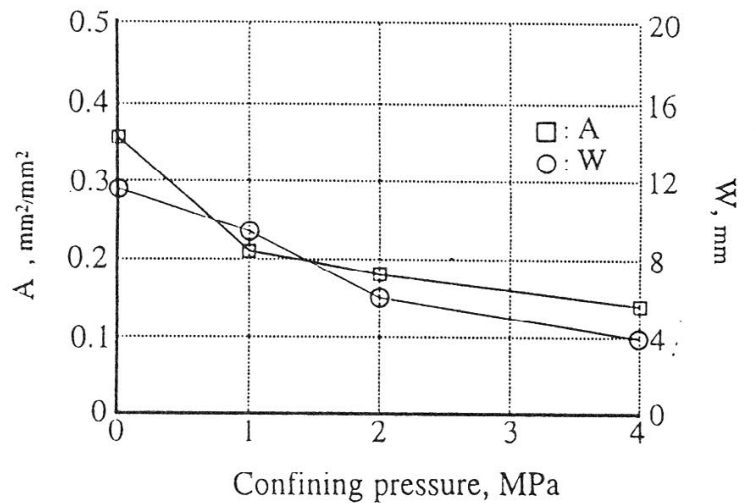

Fig. 12 Normalizes highly damaged area (A) and width (W) of the damaged part at the middle line in Fig. 11-confining pressure relation.

Fig. 11 are shown in Fig. 12 under increasing confining pressure.

\section{Discussion and Conclusions}

The distribution of mineral grains strongly affects the strength of crystal rocks. First, we tried to observe microdamages in the marble specimen, and then simulated the behavior on the basis of the fracture mechanics theory. Lastly, we observed the effect of confining pressure on damage localization.

At a low confining pressure, the local stress that is developed at tips of triple-point junctions eventually overcomes the overall compressive stress imposed by the confining pressure, then it results in the growth of axial grain boundary microcracks. This process leads to the opening of microcracks and the onset of dilatancy. However, as the confining pressure is increased, the shear stress working at microcrack tips may also increase. In addition, the confining pressure increases the frictional strength between microcracks.

The Mode I is the dominant mechanisms for the onset 
and growth of microcrack in marble, which is observed in our laboratory experiments by using newly developed system. It is understood that the onset of dilatancy is resulted from the opening of axial microcracks by the tensile stress acting on the microcracks which overcomes the confining pressure, and the primary mechanism for this is sliding on inclined grain boundary microcracks, producing tensile stress at the triple-point junction tips. An approximate physical model for microdamage evolution in the marble under compressive stress states was developed. The model is based on the growth of wedge-microcracks which are started from the triple-point junction (starter microcracks). This growth occurs rapidly along the $K_{I(1)}$ concentration paths (see Fig. 6) caused by the pre-existing grain boundary microcracks. The model agrees well with experimental results under uniaxial compression. Whereas, we could not observed the microcrack propagation procedure directly under triaxial stress state, because the specimen was set under insufficient light conditions.

Since the calcite is ductile at room temperature, the dislocation (that is, pre-existing grain boundary microcrack sliding) is usually activated before the tensile microcrack-tip opening occurs, which leads to plastic deformation of marble. Resultingly, surrounding damaged zone of shear fracture are due to the dislocation, and the area of the damaged zone depends on confining pressure.

It is said that the observation of microcracking and microdamage process such as the change of area of damaged zone help to study the strain localization and failure in crystalline rock.

Acknowledgments The authors are grateful to Mr. Yasumoto Ohta, graduate student of Nagoya University, for his assistance on this laboratory experiment.

\section{Nomenclature}

$K_{I}:$ Stress intensity factor

$[\mathrm{MPa} \sqrt{\mathrm{m}}]$

$K_{I C}$ : Critical stress intensity factor

$[\mathrm{MPa} \sqrt{\mathrm{m}}]$

$K_{I(1)}$ : Stress intensity tending to open the microcrack under the triaxial sate of stress

$[\mathrm{MPa} \sqrt{\mathrm{m}}]$

$K_{I(3):}$ Stress intensity tending to close the microcrack

by confining stress

$[\mathrm{MPa} \sqrt{\mathrm{m}}]$ $\sigma_{n}:$ Normal stress

$[\mathrm{MPa}]$

$\sigma_{1}:$ Axial stress

$[\mathrm{MPa}]$

$\sigma_{3}$ : Confining stress

$[\mathrm{MPa}]$

$\tau$ : Shear stress

$[\mathrm{MPa}]$

$2 \theta$ : Wedge angle

$\left.{ }^{\circ}\right]$

$P_{3}$ : Opening force

$[\mathrm{N} / \mathrm{m}]$

$\mu \quad$ : Friction coefficient

$[-]$

$\beta$ : Constant

$[-]$

$2 a$ : Length of the pre-existing microcrack

$[\mu \mathrm{m}]$

$l \quad$ : Length of the stress-induced microcrack

$[\mu \mathrm{m}]$

$D$ : Damage parameter

$\bar{E}$ : Effective Young's modulus

$E$ : Young's modulus

$\bar{v}:$ Effective poisson's ratio

$N$ : Number of microcraks per unit volume

$\left[\mu \mathrm{m}^{-3}\right]$

$n(f)$ : Number of facets per grain

$n(g)$ : Number of grains per unit volume

$l_{s} \quad:$ Length of the triple-point junction

$\left[\mu \mathrm{m}^{-3}\right]$

$[\mu \mathrm{m}]$

\section{References}

1) Jeong, G. C., Ichikawa, Y. and Kawamoto, T. : Int. Symposium on Assesment and Prevention in Rock Engineering, Istanbul, p.335-341, (1993)

2) Jang, B. A. and Wang, H. F. : J. Geophys. Res., Vol. 96, p.19655-19664, (1991)

3) White, J. C. and White, S. H. : Tectonophysics, Vol. 78, p.613-628, (1981)

4 ) Olsson, W. A. and Peng, S. S. : Int. J. Rock Mech. 3 Min. Sci. and Geomech. Abstr., Vol.13, p.53-59, (1976)

5) Tapponnier, P. and Brace, W. F. : Int. J. Rock Mech. Min. Sci. and Geomech. Abstr., Vol.13, p.102-112, (1976)

6) Kranz, R. L. : Int. J. Rock Mech. Sci. and Geomech. Abstr., Vol.16, p.23-36, (1979)

7 ) Batzle, M., Simmons, G. and Siefgried, R. : Eos. Tran., Vol. 60, p.380, (1979)

8) Fu, Y. and Evans, A. G. : Acta Metall., Vol. 33, p.1515-1523, (1985)

9) Sih, G. C. : Handbook of Stress Intensity Factors, Lehigh University, Bethlehem, p.515, (1973)

10) Sammis, C. G. and Ashby, M. F. : Acta Metall., Vol. 34, p.511-526, (1986)

11) Tada, H., Paris, P.C. and Irwin, G. R.: The Stress Analysis of Crack Handbook, St Louis, Mo (1985)

12) Edmond, J. M. and Paterson, M. S. : Int. J. Rock Mech. Min. Sci., Vol. 9, p.161 -182 , (1972)

13) Kim, J. D. : Ph. D Thesis, Seoul University, Korea, (1988) (in Korean)

14) Budiansky, B. and O'Connell, R. J. : Int. J. Solids Structures, Vol. 12, p.81 - 97 , (1976)

15) Guedes, J. M. and Kikuchi, N. : Computer Methods in Applied Mechanics and Engineering, Vol. 83, p.143-198, (1990)

\section{三軸応力下の大理石におけるマイクロ損傷進展}

\section{鄭教澈 ${ }^{1}$ 市川 康 明 ${ }^{2}$}

応力拡大係数を用いて均一な細粒大理石におけるマイク口損 傷進展モデルをシミュレートした。このモデルは, 先在粒界マ イクロクラックの三重接合点からのクラック進展を表すことが 可能である。また, その損傷進展を, 新しく開発された実験シ ステムによる圧縮試験を行い, 実際に観察した。

その結果, 載荷軸に平行なモード I のマイクロクラックは, 残り二つの傾いたマイクロクラックの接合点付近で起こるすべ りによって開口することがわかった。これは, マイクロクラッ クが進展する主なメカニズムである。また, マイクロ損傷領域
は, すべりに伴い大理石を構成する方解石の移動によって発達 することがわかった。これによって, 損傷領域は, 拘束圧が増 加するとその領域は隇少することから, 拘束圧に依存すること がわかった。

最後に, 損傷進展モデルは, 実験結果をよく表していること あわかった。

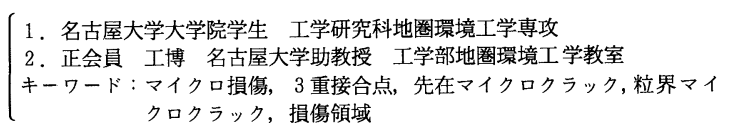

